University of Nebraska - Lincoln

DigitalCommons@University of Nebraska - Lincoln

Climatic controls of aboveground net primary production in semi-arid grasslands along a latitudinal gradient portend low sensitivity to warming

\author{
Whitney Mowll \\ Colorado State University \\ Dana M. Blumenthal \\ USDA-ARS, Dana.Blumenthal@ars.usda.gov \\ Karie Cherwin \\ Colorado State University \\ Anine Smith \\ Colorado State University \\ Amy J. Symstad \\ US Geological Survey, asymstad@usgs.gov \\ See next page for additional authors
}

Follow this and additional works at: https://digitalcommons.unl.edu/usdaarsfacpub

Mowll, Whitney; Blumenthal, Dana M.; Cherwin, Karie; Smith, Anine; Symstad, Amy J.; Vermeire, Lance T.; Collins, Scott L.; Smith, Melinda D.; and Knapp, Alan K., "Climatic controls of aboveground net primary production in semi-arid grasslands along a latitudinal gradient portend low sensitivity to warming" (2015). Publications from USDA-ARS / UNL Faculty. 1608.

https://digitalcommons.unl.edu/usdaarsfacpub/1608

This Article is brought to you for free and open access by the U.S. Department of Agriculture: Agricultural Research Service, Lincoln, Nebraska at DigitalCommons@University of Nebraska - Lincoln. It has been accepted for inclusion in Publications from USDA-ARS / UNL Faculty by an authorized administrator of DigitalCommons@University of Nebraska - Lincoln. 


\section{Authors}

Whitney Mowll, Dana M. Blumenthal, Karie Cherwin, Anine Smith, Amy J. Symstad, Lance T. Vermeire, Scott L. Collins, Melinda D. Smith, and Alan K. Knapp 


\title{
Climatic controls of aboveground net primary production in semi-arid grasslands along a latitudinal gradient portend low sensitivity to warming
}

\author{
Whitney Mowll · Dana M. Blumenthal · Karie Cherwin · \\ Anine Smith · Amy J. Symstad • Lance T. Vermeire • \\ Scott L. Collins · Melinda D. Smith · Alan K. Knapp
}

Received: 1 May 2014 / Accepted: 13 January 2015 / Published online: 12 February 2015

This document is a U.S. government work and is not subject to copyright in the United States.

(C) Springer-Verlag Berlin Heidelberg 2015

\begin{abstract}
Although climate models forecast warmer temperatures with a high degree of certainty, precipitation is the primary driver of aboveground net primary production (ANPP) in most grasslands. Conversely, variations in temperature seldom are related to patterns of ANPP. Thus forecasting responses to warming is a challenge, and raises the question: how sensitive will grassland ANPP be to warming? We evaluated climate and multi-year ANPP data (67 years) from eight western US grasslands arrayed along mean annual temperature (MAT; $\sim 7-14{ }^{\circ} \mathrm{C}$ ) and mean annual precipitation (MAP; $\sim 250-500 \mathrm{~mm}$ ) gradients. We
\end{abstract}

Communicated by Russell K. Monson.

Electronic supplementary material The online version of this article (doi:10.1007/s00442-015-3232-7) contains supplementary material, which is available to authorized users.

W. Mowll $\cdot$ K. Cherwin · A. Smith $\cdot$ M. D. Smith .

A. K. Knapp $(\triangle)$

Department of Biology and Graduate Degree Program

in Ecology, Colorado State University, Fort Collins,

CO 80523, USA

e-mail: aknapp@colostate.edu

D. M. Blumenthal

US Department of Agriculture, Agricultural Research Service,

1701 Centre Avenue, Fort Collins, CO 80526, USA

A. J. Symstad

US Geological Survey, Northern Prairie Wildlife Research

Center, 26611 US Highway 385, Hot Springs, SD 57747, USA

L. T. Vermeire

USDA-ARS Fort Keogh LARRL, 243 Fort Keogh Road,

Miles City, MT 59301, USA

S. L. Collins

Department of Biology, University of New Mexico, Albuquerque,

NM 87131, USA used regression and analysis of covariance to assess relationships between ANPP and temperature, as well as precipitation (annual and growing season) to evaluate temperature sensitivity of ANPP. We also related ANPP to the standardized precipitation evaporation index (SPEI), which combines precipitation and evapotranspiration to better represent moisture available for plant growth. Regression models indicated that variation in growing season temperature was negatively related to total and graminoid ANPP, but precipitation was a stronger predictor than temperature. Growing season temperature was also a significant parameter in more complex models, but again precipitation was consistently a stronger predictor of ANPP. Surprisingly, neither annual nor growing season SPEI were as strongly related to ANPP as precipitation. We conclude that forecasted warming likely will affect ANPP in these grasslands, but that predicting temperature effects from natural climatic gradients is difficult. This is because, unlike precipitation, warming effects can be positive or negative and moderated by shifts in the $\mathrm{C}_{3} / \mathrm{C}_{4}$ ratios of plant communities.

Keywords Climate change - Precipitation - Temperature Standardized precipitation evaporation index .

Evapotranspiration

\section{Introduction}

Of the predicted climatic changes forecast to occur due to anthropogenic disruption of the global climate system, the most certain of these is for increased atmospheric temperatures (IPCC 2013). Moreover, there is abundant evidence that warming is already occurring across much of the globe (Rummukainen 2012). While virtually every biome may be impacted by warming, the degree of impact is likely to 
vary, and it is therefore essential to understand how sensitive different ecosystems are to temperature change. For grassland ecosystems, precipitation has long been considered the dominant climatic driver of ecosystem function over much of the globe (Harpole et al. 2007; Merbold et al. 2009; Jung et al. 2011; Zhang et al. 2014). This has been repeatedly demonstrated for aboveground net primary production (ANPP) in site-based observational studies (Sala et al. 1992; Briggs and Knapp 1995; Jobbágy et al. 2002; Derner et al. 2008), studies across broad geographic gradients (Webb et al. 1978; Knapp and Smith 2001; Reed et al. 2009; Guo et al. 2012), and in a number of experiments in grassland ecosystems (Yahdjian and Sala 2006; Sherry et al. 2008; Cherwin and Knapp 2012). Indeed, at large spatial scales, mean annual precipitation (MAP) may account for $90 \%$ of the variation in ANPP (Sala et al. 1988).

Temperature on the other hand is seldom statistically related to spatial or temporal variation in ANPP in grasslands (Sala et al. 1988; Del Grosso and Parton 2008; Guo et al. 2014) except perhaps at global scales (e.g., Whittaker 1975; Frank and Inouye 1994; Gang et al. 2013). In experiments with warming treatments, results have been mixed with some studies showing positive responses (Lin et al. 2010), others negative responses (Niu et al. 2008, 2011; Cantarel et al. 2013), while others found little response (Fay et al. 2011; Xu et al. 2013) to increased temperatures. In one of the few studies demonstrating temperature effects on grassland ANPP across natural climatic gradients, Epstein et al. (1997) reported negative effects of temperature on ANPP in the central US. Although regression coefficients were not strong (average $r^{2} \sim 0.2-0.3$ ) temperature effects were greater in drier $(<600 \mathrm{~mm}$ MAP) than more mesic grasslands. Similarly, Wu et al. (2011) in a meta-analysis of warming experiments reported that warming often had a negative effect on productivity unless additional precipitation was added. These and other studies suggest that the primary effect of higher temperatures in many grassland ecosystems may be indirect through negative effects on water balance (Peñuelas et al. 2007; Xu et al. 2012; Dulamsuren et al. 2013).

Grasslands cover approximately a third of the earth's land surface and provide vital ecosystem services that include the sequestration of $\mathrm{C}$ in the soil, forage production and habitat critical for many species (Lal 2004; Chou et al. 2008). Because many of these grassland ecosystem services depend on productivity (often measured as ANPP), it is important to better understand the drivers of spatial and temporal patterns of productivity. ANPP is an important integrative variable of ecosystem function as well as a key component of the global $\mathrm{C}$ cycle. Given the high degree of certainty in forecasted increases in air temperatures, insight into how grassland ANPP may be affected is critical. If effects of increasing temperatures are primarily manifest through negative impacts on water balance, semi-arid and arid grasslands should be among the most sensitive ecosystems to this consequence of warming. For example, Huxman et al. (2004) inferred that ecosystems with low precipitation inputs should be the most responsive to changes in water availability, and Knapp and Smith (2001) reported that grasslands were more responsive to precipitation variability than most other ecosystem types in North America. Studies on other continents have found similar patterns ( $\mathrm{Li}$ et al. 2011; Sala et al. 2012).

Recently, De Frenne et al. (2013) advocated the use of natural gradients of climatic variation to assess ecological responses to climate change, and we adopted this approach to assess the temperature sensitivity of ANPP in semi-arid grasslands. Our goal was to assess sensitivity from a spatial perspective by relating variation in ANPP to temperature variables across a range of sites, as has been done in past ANPP precipitation studies (Sala et al. 1988; Epstein et al. 1997; Huxman et al. 2004; Verón et al. 2005). The analysis was based on data from eight semi-arid native grasslands with collectively 67 years of ANPP data. These sites occurred along a western US climatic gradient in which both mean annual temperature (MAT) and MAP varied two-fold. We predicted that if there were direct effects of variation in temperatures on ANPP then either a positive or negative effect of higher temperatures on ANPP would be detected. Positive effects could result from lengthening the growing season, which would be particularly important along the northern end of the gradient. Negative effects could result from exceeding the thermal optima of the dominant plants, which would likely be more important at the southern end of the gradient. Similarly, if the effects of increasing temperatures were indirect then a negative effect of temperature on ANPP would also be detected, but this would be the result of the effects of soil drying. To further examine this indirect effect, we also incorporated the standardized precipitation evaporation index (SPEI) (VicenteSerrano et al. 2010) into our analysis as an independent variable. The SPEI adjusts precipitation inputs by estimates of evapotranspiration (ET; largely driven by temperature) and thus explicitly includes the potential negative effects of temperature on water balance (Vicente-Serrano et al. 2010). Our expectation was that combining precipitation inputs with the negative effects of temperature on water balance would yield a model that explained a greater variation in ANPP than precipitation or temperature alone.

\section{Materials and methods}

Annual net primary production (ANPP; $\mathrm{g} / \mathrm{m}^{2}$ ) precipitation and temperature data (annual and growing season, 1 April to 30 September) were compiled from eight 
semi-arid grassland sites located in the Great Plains region of the US (Fig. 1; Table 1). We defined the "growing season" for all grasslands as 1 April-30 September, even though growing season length is variable across this latitudinal gradient. However, analyses with shorter growing seasons in the north and longer seasons in the south only marginally altered the results reported below. Thus, we opted to maintain a consistent growing season period for all grasslands. Across these sites, 30-year MAT varied twofold, from 7.8 to $14.2{ }^{\circ} \mathrm{C}$, as did MAP (250-500 mm). Distances between sites usually exceeded $100 \mathrm{~km}$ except for the two sites at the southern end of the gradient. These were located at the Sevilleta Long-term
Ecological Research (LTER) site and both were included because the dominant grass species differed between sites (Bouteloua gracilis vs. Bouteloua eriopoda). Data availability for ANPP varied from 3 to 16 years at individual sites (Table S1), and our primary focus was on relating patterns of ANPP and temperature across this $1,600-\mathrm{km}$ latitudinal gradient, although temporal variation was included, consistent with past studies that have assessed the sensitivity of ANPP to precipitation in grasslands (Sala et al. 1988; Huxman et al. 2004; Wu et al. 2011; Jobbágy et al. 2002; Peñuelas et al. 2007). Soils varied from sandy loams to clay (Table 1), and as expected for the central US, grassland communities were dominated by
Fig. 1 Locations of eight grasslands included in this study. Additional information for each site can be found in Tables 1 and $\mathrm{S} 1$

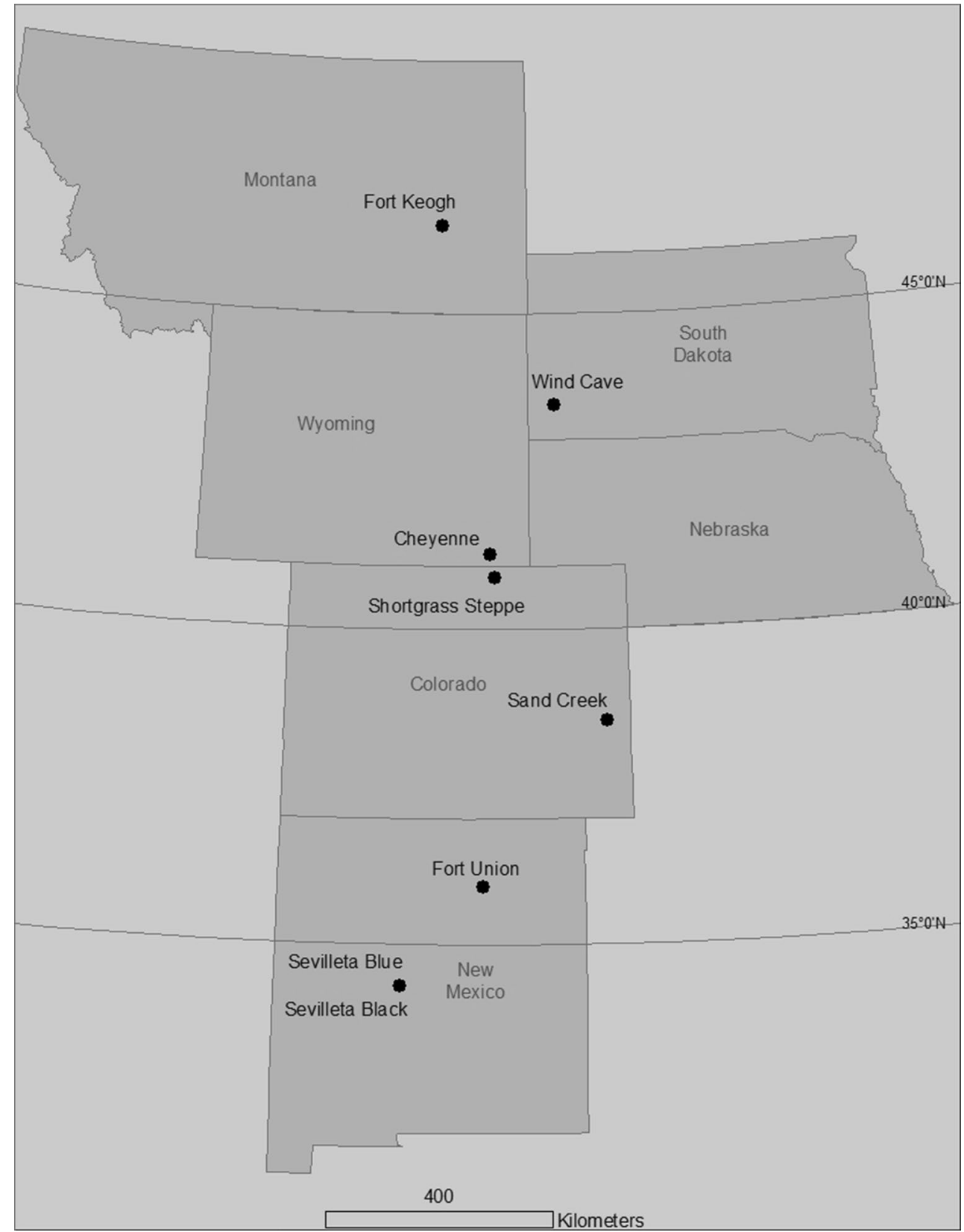


Table 1 Site characteristics of the eight grassland sites along a latitudinal gradient of semi-arid grasslands in the western US

\begin{tabular}{|c|c|c|c|c|c|c|}
\hline Site & $\operatorname{MAP}(\mathrm{mm})$ & GS.Precip. (mm) & $\operatorname{MAT}\left({ }^{\circ} \mathrm{C}\right)$ & GS.Temp. $\left({ }^{\circ} \mathrm{C}\right)$ & $\mathrm{C}_{3}: \mathrm{C}_{4}{ }^{\mathrm{a}}(\%)$ & Soil type \\
\hline Fort Keogh & 316.0 & 246.1 & 7.83 & 16.9 & $87: 13$ & Silty clay loam ${ }^{b}$ \\
\hline Wind Cave & 499.1 & 378.7 & 8.4 & 15.8 & $75: 25$ & Sandy loam ${ }^{\mathrm{c}}$ \\
\hline Cheyenne & 404.9 & 306.8 & 8.1 & 14.9 & $59: 41$ & Fine-loamy ${ }^{\mathrm{d}}$ \\
\hline SGS & 389.7 & 290.6 & 8.4 & 15.2 & $42: 58$ & Sandy loam ${ }^{\mathrm{e}}$ \\
\hline Sand Creek & 393.9 & 312.7 & 10.9 & 19.0 & $14: 86$ & Clay $^{\mathrm{f}}$ \\
\hline Fort Union & 427.0 & 317.3 & 9.9 & 16.2 & $25: 75$ & Sandy clay loam ${ }^{\mathrm{f}}$ \\
\hline Sevilleta blue & 256.0 & 178.8 & 14.2 & 21.6 & $22: 78$ & Sandy loam/clay loam ${ }^{\mathrm{g}}$ \\
\hline Sevilleta black & 256.0 & 178.8 & 14.2 & 21.6 & $20: 80$ & Sandy loam/clay loam ${ }^{\mathrm{g}}$ \\
\hline
\end{tabular}

Climate data are from the National Oceanic and Atmospheric Administration (NOAA) (www.ncdc.noaa.gov/cdoweb/datasets). More detailed information for each site can be found in the references provided after the soil type description

$M A P$ Mean annual precipitation, GS.Precip. growing season precipitation, MAT mean annual temperature (all based on 30 years of data); SGS shortgrass steppe

${ }^{a}$ Determined using aboveground net primary production (ANPP) data collected from this study, and calculated as the proportion of $\mathrm{C}_{3}$ and $\mathrm{C}_{4}$ biomass $\left(\mathrm{g} / \mathrm{m}^{2}\right)$ relative to the total

b Heitschmidt et al. (2005)

c Smith (2012)

${ }^{\mathrm{d}}$ Dijkstra et al. (2012)

e Lauenroth and Burke (2008)

${ }^{f}$ Cherwin and Knapp (2012)

g Muldavin et al. (2008)

$\mathrm{C}_{3}$ plants in the northern sites grading to $\mathrm{C}_{4}$ dominance in the southern sites (Teeri and Stowe 1976; Epstein et al. 1997; Table 1). Sites were not burned or grazed by livestock during the years that ANPP data were collected.

\section{ANPP estimates}

Methods used for estimating ANPP differed among sites. In the six northern sites, ANPP was estimated by harvesting peak or end of season biomass, sorting by species, then drying and weighing. Plot sizes varied from 0.1 to $0.25 \mathrm{~m}^{2}$ and the number of harvested plots was $>10 /$ year at each site except at Cheyenne, where $n=5$. ANPP estimates from the two southern sites were based on non-destructive allometric methods in which volume estimates were made for individual plants and ANPP was estimated using speciesspecific equations (Muldavin et al. 2008). For each site, total ANPP and ANPP of specific functional types including graminoids (grasses and sedges), forbs, and $\mathrm{C}_{3}$ and $\mathrm{C}_{4}$ photosynthetic pathways were estimated. Woody plants were included when estimating total ANPP, but they were a minor component of ANPP at all sites, therefore they were not analyzed as a functional group.

Climate data (including annual temperature and precipitation, as well as growing season temperature and precipitation) were compiled from daily site weather records or nearby weather stations ( $<15 \mathrm{~km}$ from study site). Many parameters (e.g., maximum and minimum values) at many temporal scales (daily, monthly, annually) were initially considered and explored, but growing season and annual values were the most informative. Further details on each site as well as ANPP sampling and climate data can be found in the references in Table 1 and in the Electronic Supplementary Material (Table S2).

Data analysis

We related patterns of ANPP to variation in temperature and precipitation in three ways. First, we combined the 67 years of data available from all sites with corresponding climatic data to evaluate simple and multiple linear regression models relating temperature and precipitation to ANPP. We focused on simple linear and multiple regressions, (procREG, SAS version 9.3; SAS, Cary, NC) initially in order to more directly compare our results with other regional scale analyses. Further, non-linear models did not provide additional explanatory power. Because the number of years of data varied among sites and those sites with the greatest number of years (the most northern and the two southern sites; Table S1) could dominate and bias relationships, we calculated site means for ANPP and climate data. This eliminated temporal variability and limited our statistical power to the number of sites (eight), but allowed us to determine if using all 67 years of data led to qualitatively different relationships from those based on site means. Second, the combined data set was analyzed with analysis of covariance (ANCOVA; proc MIXED) 
Table 2 Results for simple linear regression models relating climatic variables to ANPP (total, graminoid and the proportion of ANPP from $\mathrm{C}_{3}$ plants)

\begin{tabular}{|c|c|c|c|c|}
\hline Dependent variable & Parameter & Regression coefficient & $p$-value & $r^{2}$ \\
\hline \multirow[t]{6}{*}{ Total ANPP } & Annual temperature & -5.32 & 0.019 & 0.08 \\
\hline & Annual precipitation & 0.33 & $<0.0001$ & 0.39 \\
\hline & Annual SPEI & 31.86 & $<0.0001$ & 0.28 \\
\hline & Growing season temperature & -7.67 & 0.002 & 0.14 \\
\hline & Growing season precipitation & 0.31 & $<0.0001$ & 0.31 \\
\hline & Growing season SPEI & 31.65 & $<0.0001$ & 0.30 \\
\hline \multirow[t]{4}{*}{ Graminoid ANPP } & Annual temperature & -6.38 & 0.0002 & 0.15 \\
\hline & Annual precipitation & 0.31 & $<0.0001$ & 0.43 \\
\hline & Growing season temperature & -8.30 & 0.001 & 0.20 \\
\hline & Growing season precipitation & 0.30 & $<0.0001$ & 0.40 \\
\hline \multirow[t]{2}{*}{ Relative $\mathrm{C}_{3}$ ANPP } & Annual temperature & -0.07 & $<0.0001$ & 0.43 \\
\hline & Growing season temperature & 0.27 & -0.06 & $<0.0001$ \\
\hline
\end{tabular}

Only significant relationships are shown. When temperature and precipitation variables were combined in multiple regression models, none were significant, nor were any regression models significant for forb ANPP

SPEI Standardized precipitation evaporation index (estimates site water balance by combining precipitation inputs with estimates of evapotranspirational losses)

models that included site as a fixed effect, along with temperature and precipitation variables and all interaction terms. Finally, we downloaded SPEI values (Vicente-Serrano et al. 2010, from www.sac.csic.es) based on annual and growing season periods for each site and related these to patterns of ANPP. SPEI includes an estimate of ET driven primarily by temperature, thus by comparing SPEI-ANPP relationships to precipitation-ANPP relationships, we could explicitly assess the negative and indirect effects of temperature on water balance and consequently ANPP.

All models were evaluated for total ANPP, graminoid, forb, and the proportion of ANPP comprising $\mathrm{C}_{3}$ species, as dependent variables. The latter dependent variable (which ranged in magnitude from $\sim 90$ to $<5 \%$ ) was included because relative abundance of photosynthetic types was less variable from year to year than absolute ANPP values. This allowed us to focus more on broad-scale climatic drivers of ANPP by photosynthetic pathway.

Akaike's information criterion (AIC) (Johnson and Omland 2004) was used to select those models that best fit the patterns of variation in ANPP (see Table S3, Supplementary Information for all candidate models). The AIC model selection procedure (SAS proc GLM select) compared each candidate model and assigned them an AIC value based on the each model's goodness of fit, taking into account the number of parameters by penalizing each model for additional terms. The model with the lowest AIC value was selected as the best model. To estimate the relative importance of particular model parameters, Akaike weights $(w)$ were summed from those models that included the term of interest (Johnson and Omland 2004). On a scale of $0-1$, the parameters were assigned a weight based on model comparisons. Parameters in which $w$ was near one were deemed the most important. We calculated $w$ with MuMIn in R version 3.0.2 (www.r-project.org).

Finally, following Epstein et al. (1997), data were parsed into narrow ranges of precipitation (100- and 200-mm bins) to minimize variation in precipitation and increase the potential for temperature sensitivity to be manifest. Simple linear regression analyses were then conducted for those subsets of the data ( $n=7-56$ years depending on the particular range of precipitation binned).

\section{Results}

Both annual and growing season precipitation were positively correlated with total ANPP in simple regression models (Table 2; Fig. 2) and accounted for 39 and $31 \%$ of the variance in ANPP, respectively. In contrast, annual and growing season temperatures were negatively correlated with ANPP (Table 2; Fig. 2) and explained 8 and $14 \%$ of the variance, respectively. When site means were used, precipitation-ANPP relationships remained statistically significant $(p<0.0001$; Fig. 2, left inset), whereas temperatureANPP relationships were not significant (although trends were similar; Fig. 2, right inset). The addition of temperature variables in multiple regression models did not improve the explanatory power of precipitation alone. However, despite temperature's relatively minimal predictive power in simple and multiple regressions, ANCOVA models selected by AIC included growing season temperature along with site, annual 


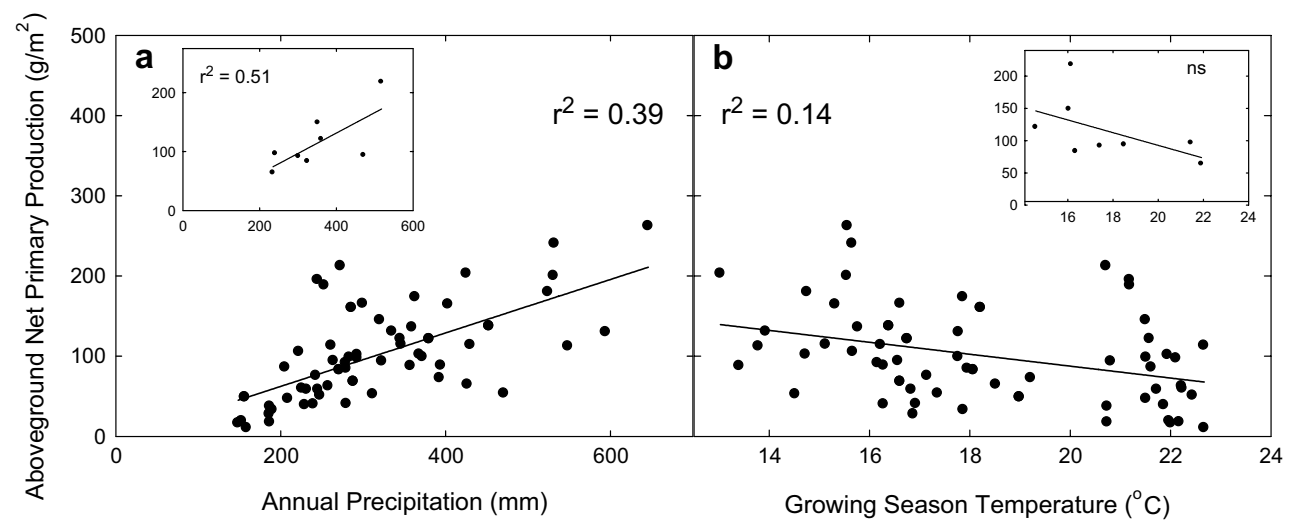

Fig. 2 Simple linear regression models that best fit patterns of aboveground net primary production (ANPP). a Relationship between annual precipitation (An.Precip.) and aboveground net primary production (ANPP) across eight grasslands (ANPP $=-2.90+0.33 \times$ An.Precip.). Inset Relationship based on site means of ANPP and precipitation
(ANPP $=-7.32+0.35 \times$ An.Precip.). $\mathbf{b}$ Relationship between ANPP and growing season temperature (GS.Temp.) across eight grasslands $(\mathrm{ANPP}=240.87-7.67 \times$ GS.Temp.). Inset Relationship based on site means of ANPP and temperature. $n s$ Not significant

Table 3 Results from analyses of covariance relating climatic variables and site as a fixed effect to total ANPP and functional types

\begin{tabular}{|c|c|c|c|c|c|}
\hline \multicolumn{6}{|c|}{ Selected models using AIC } \\
\hline Dependent variable & Model & Parameters & AIC & $w$ & $R^{2}$ \\
\hline \multirow[t]{5}{*}{ Overall ANPP } & Site GS.Temp. An.Precip. GS.Temp. $\times$ An.Precip. & & 572.35 & & 0.61 \\
\hline & & Site & & 1.00 & \\
\hline & & GS.Temp. & & 0.81 & \\
\hline & & An.Precip. & & 1.00 & \\
\hline & & GS.Temp. $\times$ An.Precip. & & 0.55 & \\
\hline \multirow[t]{5}{*}{ Graminoid } & Site GS.Temp. An.Precip. GS.Temp. $\times$ An.Precip. & & 544.24 & & 0.63 \\
\hline & & Site & & 1.00 & \\
\hline & & GS.Temp. & & 0.58 & \\
\hline & & An.Precip. & & 1.00 & \\
\hline & & GS.Temp. $\times$ An.Precip. & & 0.20 & \\
\hline \multirow[t]{4}{*}{ Forb } & Site An.Precip. An.Precip. $\times$ Site & & 398.44 & & 0.52 \\
\hline & & Site & & 1.00 & \\
\hline & & An.Precip. & & 1.00 & \\
\hline & & An.Precip. $\times$ Site & & 0.99 & \\
\hline \multirow[t]{6}{*}{ Relative $C_{3}$} & Site GS.Temp. An.Precip. An.Precip. $\times$ Site GS.Temp. $\times$ An.Precip. & & -189.96 & & 0.89 \\
\hline & & Site & & 1.00 & \\
\hline & & GS.Temp. & & 0.98 & \\
\hline & & An.Precip. & & 1.00 & \\
\hline & & An.Precip. $\times$ Site & & 0.98 & \\
\hline & & GS.Temp. $\times$ An.Precip. & & 0.96 & \\
\hline
\end{tabular}

Akaike's information criterion $(A I C)$ was used to select models with the best fit and the least complexity. Simple and multiple regression models were included as candidate models, but none were selected. Models were selected for each of the functional types: total ANPP, graminoid, forb, and relative $\mathrm{C}_{3}$ ANPP. Akaike weights $(w)$ were used to assess how individual parameters improved the model selected

GS Growing season, An. annual, Temp. temperature, Precip. precipitation

precipitation and a growing season temperature $\times$ annual precipitation interaction term (Table 3). Although site and annual precipitation were the most influential parameters in the model $(w=1.0)$, growing season temperature contributed substantially $(w=0.81)$, while the interaction term was the least important variable ( $w=0.55$; Table 3 ).

Graminoids comprised a large proportion of total ANPP at all sites and thus both annual and growing season 


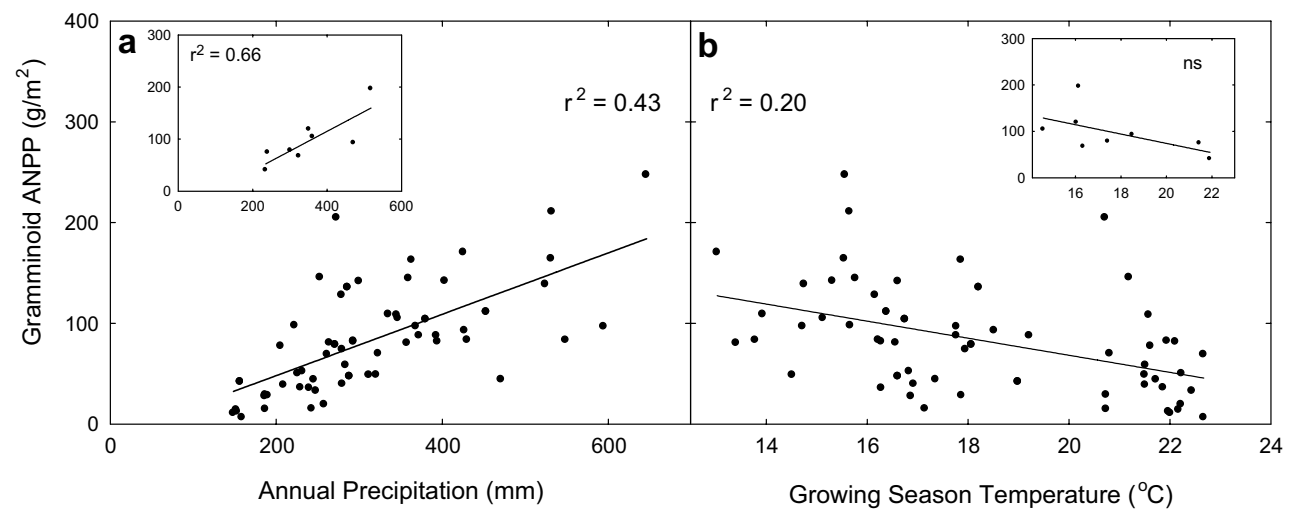

Fig. 3 Simple linear regression models that best fit patterns of graminoid ANPP. a Relationship between An.Precip. and graminoid ANPP (Graminoid ANPP $=-14.58+0.31 \times$ An.Precip.). b Relationship between GS.Temp. and graminoid ANPP

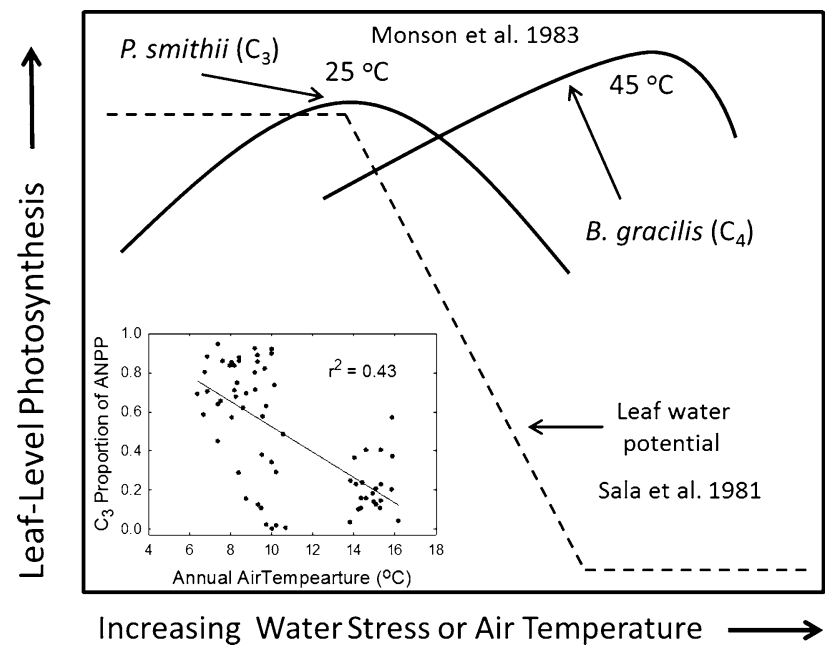

Fig. 4 Contrasting responses of leaf-level photosynthesis in two dominant semi-arid grassland grasses to alterations in temperature and increasing water stress. Along the north to south climatic gradient in this study (Fig. 1), there is a shift in the proportion of ANPP resulting from plants with the $\mathrm{C}_{3}$ vs. $\mathrm{C}_{4}$ photosynthetic pathways (inset relationship from this study; Table 1). The two dominant grasses along this gradient, Pascopyrum smithii and Bouteloua gracilis, both have broad photosynthetic response surfaces to varying temperatures and their respective temperature optima differ by $20^{\circ} \mathrm{C}$ (Monson et al. 1983). Shifts in the abundance of $\mathrm{C}_{3}$ and $\mathrm{C}_{4}$ species along this gradient may moderate apparent temperature sensitivity of ANPP, whereas effects of temporal changes in temperature for both $\mathrm{C}_{3}$ and $\mathrm{C}_{4}$ grasses will depend upon whether temperatures are shifting towards or away from thermal optima. In contrast to temperature, responses of photosynthesis to water stress (dashed line) show a strong threshold response for all plant species [example shown is for $B$. gracilis (Sala et al. 1981)] and thus ANPP responses to changes in precipitation inputs are more likely to be consistently strong along the entire climatic gradient (spatially and temporally). Combined, spatial shifts in species-level traits and differences in the nature of physiological responses to change in water vs. temperature are key mechanisms explaining why precipitation but not temperature is a strong predictor of latitudinal variation in ANPP in western US semiarid grasslands
(Graminoid ANPP $=-233.20-8.30 \times$ GS.Temp.). Insets Relationships based on site means for each of the eight grasslands $(\mathrm{ANPP}=-36.78+0.38 \times$ An.Precip. $)$. For abbreviations, see Fig. 2

precipitation were also strongly correlated with graminoid ANPP; annual precipitation again was the best predictor (Fig. 3; Table 2). In simple regression models, annual and growing season temperatures were highly correlated with graminoid ANPP, but similar to total ANPP, annual and growing season temperatures explained much less of the variability $\left(r^{2}=0.15\right.$ and 0.20 respectively; Fig. 3; Table 2). Similar to the results for total ANPP, when data were combined at the site level, relationships were statistically significant for precipitation but not temperature (Fig. 3, inset).

The best ANCOVA model for graminoid ANPP included the same parameters important for total ANPP (site, growing season temperature, annual precipitation, and a growing season temperature $\times$ annual precipitation interaction term). For graminoids, site and annual precipitation were the most important model parameters, both with a weight of 1.0, whereas growing season temperature was less important ( $w=0.58$; Table 3$)$. In contrast to graminoids, forbs comprised a much smaller and more variable proportion of total ANPP among sites and as a result, no simple or multiple regression models with temperature or precipitation parameters were significant. The best ANCOVA model for forb ANPP included site, annual precipitation, and an interaction between these two terms (Table 3).

In contrast to absolute ANPP values, the proportion of ANPP from $\mathrm{C}_{3}$ plants was strongly correlated with both growing season and annual temperature, but not with precipitation. In simple regressions, annual temperature was a better predictor of relative $\mathrm{C}_{3}$ ANPP than growing season temperature ( $r^{2}=0.43$ and 0.27 respectively; Table 2$)$, and was inversely related to $\mathrm{C}_{3}$ production (Fig. 4). The best model selected using $w$ included site, growing season temperature, annual precipitation and the interaction terms annual precipitation $\times$ site and growing season temperature $\times$ annual precipitation (Table 3 ). 
Despite the combination of precipitation and temperature effects in SPEI values, simple regressions of growing season $\left(r^{2}=0.30\right)$ and annual SPEI $\left(r^{2}=0.28\right)$, although highly significant, explained less of the variation in ANPP than precipitation alone (Table 2). Furthermore, parsing the data into 100- and 200-mm ranges of precipitation after Epstein et al. (1997) did not improve relationships between ANPP and temperature variables along this gradient.

\section{Discussion}

The goal of this study was to assess the temperature sensitivity of ANPP in semi-arid grasslands along a natural climatic gradient where temperature and precipitation both varied by twofold from north to south. Although growing season temperature was found to be negatively related to both total and graminoid ANPP with simple linear regression models, annual precipitation was a much stronger predictor of patterns of ANPP than temperature. Thus, our study was consistent with previous research (Lauenroth and Sala 1992; Li et al. 2011; Knapp et al. 2002; Vermeire et al. 2009; Sala et al. 1988), except that the amount of variance explained by precipitation was substantially less along this latitudinal gradient than in many of these other studies. Because temperature and precipitation were negatively correlated across these sites, inferences regarding temperature sensitivity are challenging. However, with models that accounted for site variation and interactions between temperature and precipitation, growing season temperature was still identified as a significant model parameter explaining variation in ANPP, albeit secondary to precipitation. A similar conclusion of weak but significant temperature effects in models dominated by water availability terms was reached in an analysis of tree growth in eucalypt forests arrayed along climatic gradients in Australia (Bowman et al. 2014).

Past studies (experimental and observational) have demonstrated negative effects of temperature on ANPP, and these have been argued to be indirect due to increased ET and reduced water availability to plants at higher temperatures (Epstein et al. 1997; Niu et al. 2008; Engel et al. 2009; Dulamsuren et al. 2013; Xu et al. 2013). We were unable to demonstrate such a negative statistical relationship between temperature and ANPP when we analyzed subsets of the data in which precipitation variation was restricted to narrow ranges (Epstein et al. 1997). Perhaps more surprising, however, was that simple linear regression models based on the SPEI explained less variance along this natural climatic gradient than precipitation alone. This suggests that across these eight semi-arid grasslands, the indirect effect of temperature on site water balance was not consistent with regard to effects of temperature on ANPP. This result and the inclusion of significant precipitation $\times$ temperature interaction terms in the best-fit models suggest that the relationship between temperature and ANPP is more complex than the precipitation-ANPP relationship (Vicente-Serrano et al. 2013).

Why is ANPP sensitivity to temperature difficult to detect along natural climate gradients?

The strong interdependency of temperature and precipitation in determining ecosystem function is well known (Rosenzweig 1968; Kardol et al. 2010; Frank and Inouye 1994; Rustad et al. 2001), yet at local to global scales, ecosystem function and structure are usually much better correlated with precipitation patterns than temperature (e.g., Sala et al. 1988; Del Grosso and Parton 2008). The exception to this generalization is in ecosystems with abundant water (Huxman et al. 2004; Kirwan et al. 2009). Below we explore several potential reasons why temperature sensitivity is difficult to detect and why as a result, predicting responses of ANPP to forecast warming is likely to be better informed by experiments than by using natural climatic gradients.

A fundamental difference between temperature and precipitation effects on plant and ecosystem processes is that for all but the most hydric ecosystems (Knapp et al. 2008), significant reductions in precipitation will always have a negative (or at best neutral) effect on ecosystem processes. This includes both leaf-level photosynthesis and ANPP (Fig. 4; Sala et al. 1981; Heitschmidt et al. 2005). In contrast, most $\mathrm{C}$-gain processes at both the leaf and ecosystem levels have distinct thermal optima. Thus, alterations in temperature can have negative or positive impacts contingent upon temperatures shifting towards or away from thermal optima (Fig. 4). Such contingent positive or negative effects can occur on diurnal as well as seasonal time scales. Temperature impacts on $\mathrm{C}$ gain can also vary with soil moisture such that warm temperatures might positively affect ecosystem processes for several days after a substantial rain event, but have negative effects during dry periods when soil water is low (Niu et al. 2008; Zhou et al. 2008). Such contingent effects are likely reflected in the temperature $\times$ precipitation interaction term in the models that explained variation in ANPP the best (Table 3).

In addition, precipitation tends to vary much more than temperature at interannual time scales. Based on long-term (30-year) climatic records for these eight sites, coefficients of variation $(\mathrm{CV})$ for annual temperature were always less and often less than half the magnitude of the CVs for precipitation (Table S2). This pattern was also evident in the 67-year data set. Thus, even if ANPP was equally sensitive to alterations in temperature and precipitation, greater interannual variability in precipitation would increase the chance of detecting significant precipitation sensitivity relative to temperature. 
Less interannual variation in temperature vs. precipitation may also lead to the strong correlation of MAT with the distribution of species with $\mathrm{C}_{3}$ and $\mathrm{C}_{4}$ photosynthetic pathways at regional to continental scales in grasslands (Teeri and Stowe 1976; Tieszen et al. 1979; Wittmer et al. 2010). Indeed in this study, precipitation better explained patterns of ANPP but variation in temperature explained more variance in the contribution of $\mathrm{C}_{3}$ species to ANPP. Greater stability in temperatures may allow species with different photosynthetic traits to align more strongly along temperature than precipitation gradients. This strong sorting of $\mathrm{C}_{3} / \mathrm{C}_{4}$ photosynthetic pathways was clearly evident along the natural climatic gradient in this study (Table 1; Fig. 4). Differences in temperature optima of the dominant $\mathrm{C}_{3}$ and $\mathrm{C}_{4}$ grasses and their shift in abundance from north to south along a temperature gradient, combined with variable effects of alterations in temperature (Fig. 4), all likely contribute to low apparent temperature sensitivity of ANPP in this region and perhaps in many others.

Despite low sensitivity of ANPP to temperature along this natural climatic gradient, we are hesitant to conclude that these grasslands will be insensitive to forecasted warming. Indeed, because of low interannual variability in temperature, directional shifts in MAT by only a few degrees may lead to temperatures that routinely exceed historic levels (Mora et al. 2013), particularly for temperature extremes (Smith 2011). Further, because shifts in community composition and species distributions (including alterations in $\mathrm{C}_{3} / \mathrm{C}_{4}$ composition) to directional changes in climate require more time than physiological responses of extant species (Smith et al. 2009; Vermeire et al. 2009), sensitivity of ANPP to future warming may lag the more immediate responses to changes in precipitation. Thus, although using natural climatic gradients for ecological climate change research may have many advantages (De Frenne et al. 2013), and such gradients have been particularly useful for providing insights into precipitation as a driver of ANPP, long-term experimentation may be required to better forecast ecosystem responses to warming (Knapp et al. 2012).

Author contribution statement AKK conceived of the study; WM conducted the analysis; WM, MDS and AKK wrote the manuscript; DMB, KC, AS, AJS, LTV and SLC contributed data and edited the manuscript.

Acknowledgments We thank Dr Ann Hess, Colorado State University, for her significant assistance with the statistical analysis. We also thank the technicians and scientists at the SGS and the Sevilleta LTER sites for collecting, managing and sharing ANPP data, and the scientists associated with the Prairie Heating and $\mathrm{CO}_{2}$ Enrichment (PHACE) project in Cheyenne, Wyoming. PHACE was supported by the US Department of Agriculture-Agricultural Research
Service Climate Change, Soils and Emissions Program and the US National Science Foundation (NSF; DEB no. 1021559). Additional research support for this analysis came from the NSF Macrosystems Biology Program. Any use of trade, firm, or product names is for descriptive purposes only and does not imply endorsement by the US government.

\section{References}

Bowman DMJS, Williamson GJ, Keenan RJ, Prior LD (2014) A warmer world will reduce tree growth in evergreen broadleaf forests: evidence from Australian temperate and subtropical eucalypt forests. Glob Ecol Biogeogr 23:925-934

Briggs JM, Knapp AK (1995) Interannual variability in primary production in tallgrass prairie: climate, soil moisture, topographic position, and fire as determinants of aboveground biomass. Am J Bot 82:1024-1030

Cantarel AAM, Bloor JMG, Soussana JF (2013) Four years of simulated climate change reduces above-ground productivity and alters functional diversity in a grassland ecosystem. J Veg Sci 24:113-126

Cherwin K, Knapp AK (2012) Unexpected patterns of sensitivity to drought in three semi-arid grasslands. Oecologia 169:845-852

Chou WW, Silver WL, Jackson RD, Thompson AW, Allen-Diaz B (2008) The sensitivity of annual grassland carbon cycling to the quantity and timing of rainfall. Glob Change Biol 14:1382-1394

De Frenne P, Graae BJ, Rodriguez-Sanchez F, Kolb A, Chabrerie O, Decocq G, De Kort H, De Schrijver A, Diekmann M, Eriksson O, Gruwez R, Hermy M, Lenoir J, Plue J, Coomes DA, Verheyen K (2013) Latitudinal gradients as natural laboratories to infer species' responses to temperature. J Ecol 101:784-795

Del Grosso S, Parton W (2008) Global potential net primary production predicted from vegetation class, precipitation, and temperature. Ecology 83:2117-2126

Derner JD, Hess BW, Olson RA, Schuman GE (2008) Functional group and species responses to precipitation in three semi-arid rangeland ecosystems. Arid Land Res Manage 22:81-92

Dijkstra FA, Pendall E, Morgan JA, Blumenthal DM, Carrillo Y, LeCain DR, Follett RF, Williams DG (2012) Climate change alters stoichiometry of phosphorus and nitrogen in a semiarid grassland. New Phytol 196:807-815

Dulamsuren C, Wommelsdorf T, Zhao FJ, Xue YQ, Zhumadilov BZ, Leuschner C, Hauck M (2013) Increased summer temperatures reduce the growth and regeneration of Larix sibirica in southern boreal forests of Eastern Kazakhstan. Ecosystems 16:1536-1549

Engel EC, Weltzin JF, Norby RJ, Classen AT (2009) Responses of an old-field plant community to interacting factors of elevated $\left[\mathrm{CO}_{2}\right]$, warming, and soil moisture. J Plant Ecol 2:1-11

Epstein HE, Lauenroth WK, Burke IC (1997) Effects of temperature and soil texture on ANPP in the US Great Plains. Ecology 78:2628-2631

Fay PA, Blair JM, Smith MD, Nippert JB, Carlisle JD, Knapp AK (2011) Relative effects of precipitation variability and warming on tallgrass prairie ecosystem function. Biogeosciences 8:3053-3068

Frank DA, Inouye RS (1994) Temporal variation in actual evapotranspiration of terrestrial ecosystems-patterns and ecological implications. J Biogeogr 21:401-411

Gang C, Zhou W, Li J, Chen Y, Mu S, Ren J, Chen J, Groisman PY (2013) Assessing the spatiotemporal variation in distribution, extent and NPP of terrestrial ecosystems in response to climate change from 1911 to 2000. PLoS One. doi:10.1371/journal. pone.0080394 
Guo Q, Hu Z, Li S, Li X, Sun X, Yu G (2012) Spatial variations in aboveground net primary productivity along a climate gradient in Eurasian temperate grassland: effects of mean annual precipitation and its seasonal distribution. Glob Change Biol 18:3624-3631

Guo L, Wu S, Zhao D, Yunhe Y, Leng G, Zhang Q (2014) NDVIbased vegetation change in Inner Mongolia from 1982 to 2006 and its relationship to climate at the biome scale. Adv Meteorol 2014. doi: $10.1155 / 2014 / 692068$

Harpole SW, Potts DL, Suding KN (2007) Ecosystem responses to water and nitrogen amendment in a California grassland. Glob Change Biol 13:2341-2348

Heitschmidt RK, Klement KD, Haferkamp MR (2005) Interactive effects of drought and grazing on Northern Great Plains rangelands. Rangel Ecol Manage 58:11-19

Huxman TE, Smith MD, Fay PA, Knapp AK, Shaw RM, Loik ME, Smith SD, Tissue DT, Zak JC, Weltzin JF, Pockman WT, Sala OE, Haddad BM, Harte J, Koch GW, Schwinning S, Small EE, Williams DG (2004) Convergence across biomes to a common rain-use efficiency. Nature 429:651-654

IPCC (2013) Climate change 2013. The physical science basis. Working group I contribution to the fifth assessment report of the Intergovernmental Panel on Climate Change technical summary. Cambridge University Press, Cambridge

Jobbágy EG, Sala OE, Paruelo JM (2002) Patterns and controls of primary production in the Patagonian Steppe: a remote sensing approach. Ecology 83:307-319

Johnson JB, Omland KS (2004) Model selection in ecology and evolution. Trends Ecol Evol 19:101-108

Jung M, Reichstein M, Margolis HA, Cescatti A, Richardson AD, Arain MA, Arneth A, Bernhofer C, Bonal D, Chen J, Gianelle D, Gobron N, Kiely G, Kutsch W, Lasslop G, Law BE, Lindroth A, Merbold L, Montagnani L, Moors EJ, Papale D, Sottocornola M, Vaccari F, Williams C (2011) Global patterns of land-atmosphere fluxes of carbon dioxide, latent heat, and sensible heat derived from eddy covariance, satellite, and meteorological observations. J Geophys Res 116:G00J07. doi:10.1029/2010JG001566

Kardol P, Cregger MA, Campany CE, Classen AT (2010) Soil ecosystem functioning under climate change: plant species and community effects. Ecology 91:767-781

Kirwan ML, Guntenspergen GR, Morris JT (2009) Latitudinal trends in Spartina alterniflora productivity and the response of coastal marshes to global change. Glob Change Biol 15:1982-1989

Knapp AK, Smith MD (2001) Variation among biomes in temporal dynamics of aboveground primary production. Science 291:481-484

Knapp AK, Fay PA, Blair JM, Collins SL, Smith MD, Carlisle JD, Harper CW, Danner BT, Lett MS, McCarron JK (2002) Rainfall variability, carbon cycling, and plant species diversity in a mesic grassland. Science 298:2202-2205

Knapp AK, Beier C, Briske DD, Classen AT, Luo Y, Reichstein M, Smith MD, Smith SD, Bell JE, Fay PA, Heisler-White JL, Leavitt SW, Sherry RY, Smith B, Weng E (2008) Consequences of more extreme precipitation regimes for terrestrial ecosystems. Bioscience 58:811-821

Knapp AK, Smith MD, Hobbie SE, Collins SL, Fahey TJ, Hansen GJA, Landis DA, La Pierre KJ, Melillo JM, Seasted TR, Shaver GR, Webster JR (2012) Past, present and future roles of longterm experiments in the LTER Network. Bioscience 62:377-389

Lal R (2004) Soil carbon sequestration to mitigate climate change. Geoderma 123:1-22

Lauenroth WK, Burke IC (eds) (2008) Ecology of the shortgrass steppe: a long-term perspective. Oxford University Press, New York

Lauenroth WK, Sala OE (1992) Long-term forage production of North American shortgrass steppe. Ecol Appl 2:397-403
Li J, Lin S, Taube F, Pan Q, Dittert K (2011) Above and belowground net primary productivity of grassland influenced by supplemental water and nitrogen in Inner Mongolia. Plant Soil 340:253-264

Lin D, Xia J, Wan S (2010) Climate warming and biomass accumulation of terrestrial plants: a meta-analysis. New Phytol 188:187-198

Merbold L, Ardo J, Arneth A, Scholes RJ, Nouvellon Y, de Grandcourt A, Archibald S, Bonnefond JM, Boulain N, Brueggemann N, Bruemmer C, Cappelaere B, Ceschia E, El-Khidir HAM, ElTahir BA, Falk U, Lloyd J, Kergoat L, Le Dantec V, Mougin E, Muchinda M, Mukelabai MM, Ramier D, Roupsard O, Timouk F, Veenendaal EM, Kutsch WL (2009) Precipitation as driver of carbon fluxes in 11 African ecosystems. Biogeosciences 6:1027-1041

Monson RK, Littlejohn RO Jr, Williams G III (1983) Photosynthetic adaptation to temperature in four species from the Colorado shortgrass steppe: a physiological model for coexistence. Oecologia 58:43-51

Mora C, Frazier AG, Longman RJ, Dacks RS, Walton MM, Tong EJ, Sanchez JJ, Kaiser LR, Stender YO, Anderson JM, Ambrosino CM, Fernandez-Silva I, Giuseffi LM, Giambelluca TW (2013) The projected timing of climate departure from recent variability. Nature 502:183-187

Muldavin EH, Moore DI, Collins SL, Wetherill KR, Lightfoot DC (2008) Aboveground net primary production dynamics in a northern Chihuahuan Desert Ecosystem. Oecologia 155:123-132

Niu S, Wu M, Han Y, Xia J, Li L, Wan S (2008) Water-mediated responses of ecosystem carbon fluxes to climatic change in a temperate steppe. New Phytol 177:209-219

Niu S, Xing X, Zhang ZHE, Xia J, Zhou X, Song B, Li L, Wan S (2011) Water-use efficiency in response to climate change: from leaf to ecosystem in a temperate steppe. Glob Change Biol 17:1073-1082

Peñuelas J, Prieto P, Beier C, Cesaraccio C, De Angelis P, de Dato G, Emmett BA, Estiarte M, Garadnai J, Gorissen A, Láng EK, Kröel-Dulay G, Llorens L, Pellizzaro G, Riis-Nielsen T, Schmidt IK, Sirca C, Sowerby A, Spano D, Tietema A (2007) Response of plant species richness and primary productivity in shrublands along a north-south gradient in Europe to seven years of experimental warming and drought: reductions in primary productivity in the heat and drought year of 2003. Glob Change Biol 13:2563-2581

Reed DN, Anderson TM, Dempewolf J, Metzger K, Serneels S (2009) The spatial distribution of vegetation types in the Serengeti ecosystem: the influence of rainfall and topographic relief on vegetation patch characteristics. J Biogeogr 36:770-782

Rosenzweig ML (1968) Net primary productivity of terrestrial communities: prediction from climatological data. Amer Nat 102:67-74

Rummukainen M (2012) Changes in climate and weather extremes in the 21st century. Clim Change 3:115-129

Rustad LE, Campbell JL, Marion GM, Norby RJ, Mitchell MJ, Hartley AE, Cornelissen JHC, Gurevitch J (2001) A meta-analysis of the response of soil respiration, net nitrogen mineralization, and aboveground plant growth to experimental ecosystem warming. Oecologia 126:543-562

Sala OE, Lauenroth WK, Parton WJ, Trlica MJ (1981) Water status of soil and vegetation in a shortgrass steppe. Oecologia 48:327-331

Sala OE, Parton WJ, Joyce LA, Lauenroth WK (1988) Primary production of the central grassland region of the United State. Ecology 69:40-45

Sala OE, Lauenroth WK, Parton WJ (1992) Long-term soil water dynamics in the shortgrass steppe. Ecology 73:1175-1181

Sala OE, Gherardi LA, Reichmann L, Jobbágy E, Peters D (2012) Legacies of precipitation fluctuations on primary production: theory and data synthesis. Philos Trans R Soc B 367:3135-3144 
Sherry RA, Weng E, Arnone JA III, Johnson DW, Schimel DS, Verburg PS, Wallace LL, Luo Y (2008) Lagged effects of experimental warming and doubled precipitation on annual and seasonal aboveground biomass production in a tallgrass prairie. Glob Change Biol 14:2923-2936

Smith MD (2011) The ecological role of climate extremes: current understanding and future prospects. J Ecol 99:651-655

Smith A (2012) Ecological consequences of increased nitrogen deposition in three Northern Great Plains grasslands. Master's thesis, Colorado State University, Fort Collins

Smith MD, Knapp AK, Collins SL (2009) A framework for assessing ecosystem dynamics in response to chronic resource alterations induced by global change. Ecology 90:3279-3289

Teeri JA, Stowe LG (1976) Climatic patterns and the distribution of $\mathrm{C}_{4}$ grasses in North America. Oecologia 23:1-12

Tieszen LL, Hein D, Qvortrup SA, Troughton JH, Imbamba SK (1979) Use of $813 \mathrm{C}$ Values to determine vegetation selectivity in East African herbivores. Oecologia 37:351-359

Vermeire LT, Heitschmidt RK, Rinella MJ (2009) Primary productivity and precipitation-use efficiency in mixed-grass prairie: a comparison of northern and southern US sites. Rangel Ecol Manage 62:230-239

Verón SR, Oesterheld M, Paruelo JM (2005) Production as a function of resource availability: slopes and efficiencies are different. J Veg Sci 16:351-354

Vicente-Serrano SM, Beguería S, López-Moreno JI (2010) A multiscalar drought index sensitive to global warming: the standardized precipitation evapotranspiration index. J Clim 23:1696-1718

Vicente-Serrano SM, Gouveia C, Camarero JJ, Beguería S, Trigo R, López-Moreno JI, Azorín-Molina C, Pasho E, Lorenzo-Lacruz J, Revuelto J, Morán-Tejedaa E, Sanchez-Lorenzog A (2013) Response of vegetation to drought time-scales across global land biomes. Proc Natl Acad Sci 110:52-57
Webb W, Szarek S, Lauenroth W, Kinerson R, Smith M (1978) Primary productivity and water use in native forest, grassland, and desert ecosystems. Ecology 59:1239-1247

Whittaker RH (1975) Communities and ecosystems, 2nd edn. CollierMacmillan, New York

Wittmer MHOM, Auerswald K, Bai Y, Schaufele R, Schnyder H (2010) Changes in the abundance of $\mathrm{C}_{3} / \mathrm{C}_{4}$ species of Inner Mongolia grassland: evidence from isotopic composition of soil and vegetation. Glob Change Biol 16:605-616

Wu Z, Dijkstra P, Koch GW, Penuelas J, Hungate BA (2011) Responses of terrestrial ecosystems to temperature and precipitation change: a meta-analysis of experimental manipulation. Glob Change Biol 17:927-942

Xu X, Niu S, Sherry RA, Zhou X, Zhou J, Luo Y (2012) Interannual variability in responses of belowground net primary productivity (NPP) and NPP partitioning to long-term warming and clipping in a tallgrass prairie. Glob Change Biol 18:1648-1656

Xu X, Sherry RA, Niu S, Li D, Luo Y (2013) Net primary productivity and rain-use efficiency as affected by warming, altered precipitation, and clipping in a mixed-grass prairie. Glob Change Biol 19:2753-2764

Yahdjian L, Sala OE (2006) Vegetation structure constrains primary production response to water availability in the Patagonian steppe. Ecology 87:952-962

Zhang L, Guo H, Jia G, Wylie B, Gilmanov T, Howard D, Ji L, Xiao J, Li J, Yuan W, Zhao T, Chen S, Zhou G, Kato T (2014) Net ecosystem productivity of temperate grasslands in northern China: an upscaling study. Agric For Meteorol 184:71-81

Zhou X, Weng E, Luo Y (2008) Modeling patterns of nonlinearity in ecosystem responses to temperature, $\mathrm{CO}_{2}$, and precipitation changes. Ecol Appl 18:453-466 


\section{Supplementary Material}

Climatic controls of aboveground net primary production in semi-arid grasslands along a latitudinal gradient portend low sensitivity to warming

Whitney Mowll ${ }^{1}$, Dana M. Blumenthal ${ }^{2}$, Karie Cherwin ${ }^{1}$, Anine Smith ${ }^{1}$, Amy J. Symstad ${ }^{3}$, Lance

T. Vermeire ${ }^{4}$, Scott L. Collins ${ }^{5}$, Melinda D. Smith ${ }^{1}$ and Alan K. Knapp ${ }^{1}$

${ }^{1}$ Department of Biology and Graduate Degree Program in Ecology, Colorado State University, Ft. Collins, CO, 80523, USA

${ }^{2}$ US Department of Agriculture - ARS, 1701 Centre Ave. Fort Collins, CO 80526, USA

${ }^{3}$ US Geological Survey, Northern Prairie Wildlife Research Center, 26611 U.S. Highway 385, Hot Springs, SD 57747, USA

${ }^{4}$ USDA-ARS Fort Keogh LARRL, 243 Fort Keogh Road, Miles City, MT 59301, USA

${ }^{5}$ Department of Biology, University of New Mexico, Albuquerque, NM, 87131, USA 


\section{Detailed Site Descriptions}

Table S1: Additional site data for the eight grasslands. Longitude, latitude and elevation estimates were gathered using earth.google.com. Years of data are the number of years of data used in the analyses.

\begin{tabular}{lllll}
\hline Site & $\begin{array}{l}\text { Years of } \\
\text { Available } \\
\text { Data }\end{array}$ & Longitude & Latitude & $\begin{array}{l}\text { Elevation } \\
(\mathbf{m})\end{array}$ \\
\hline Fort Keogh & 16 & $-105^{\circ} 57^{\prime} 20^{\prime \prime} \mathrm{W}$ & $46^{\circ} 22^{\prime} 55^{\prime \prime} \mathrm{N}$ & 820 \\
Wind Cave & 4 & $-103^{\circ} 25^{\prime} 16^{\prime \prime} \mathrm{W}$ & $43^{\circ} 36^{\prime} 16^{\prime \prime}$ & 1045 \\
Cheyenne & 7 & $-104^{\circ} 53^{\prime} 12^{\prime \prime} \mathrm{W}$ & $41^{\circ} 11^{\prime} 5.2^{\prime \prime} \mathrm{N}$ & 1920 \\
SGS & 9 & $-104^{\circ} 46^{\prime} 38^{\prime \prime} \mathrm{W}$ & $40^{\circ} 48^{\prime} 46^{\prime \prime} \mathrm{N}$ & 1655 \\
Sand Creek & 3 & $-102^{\circ} 30^{\prime} 22^{\prime \prime} \mathrm{W}$ & $38^{\circ} 32^{\prime} 511^{\prime} \mathrm{N}$ & 1210 \\
Fort Union & 3 & $-105^{\circ} 0^{\prime} 36^{\prime \prime} \mathrm{W}$ & $35^{\circ} 54^{\prime} 355^{\prime \prime N}$ & 2060 \\
Sevilleta Blue & 12 & $-106^{\circ} 58^{\prime} 0^{\prime \prime} \mathrm{W}$ & $34^{\circ} 20^{\prime} 00^{\prime \prime} \mathrm{N}$ & 1670 \\
Sevilleta Black & 11 & $-106^{\circ} 58^{\prime} 0 " \mathrm{~W}$ & $34^{\circ} 20^{\prime} 0$ "N & 1615 \\
\hline
\end{tabular}

\section{Mixed Grass Prairie}

Fort Keogh, $M T\left(46^{\circ} 22^{\prime} 55^{\prime \prime} \mathrm{N}-105^{\circ} 57^{\prime} 20^{\prime}\right.$ W) is an upland site in south eastern Montana that is dominated by two $\mathrm{C}_{3}$ grasses, Hesperostipa comata and Pascopyrum smithii. Both climate and productivity data collected for the Fort Keogh site were provided by the Fort Keogh United States Department of Agriculture (USDA) Agricultural Research Service (ARS) station.

Wind Cave, $S D\left(41^{\circ} 11^{\prime} 5.2^{\prime \prime} \mathrm{N}-103^{\circ} 25^{\prime} 16^{\prime \prime} \mathrm{W}\right)$ is a lowland site that is dominated by Pascopyrum smithii $\left(\mathrm{C}_{3}\right)$ and Bouteloua gracilis $\left(\mathrm{C}_{4}\right)$. Climate data were collected from the High 
Plains Regional Climate Center (HPRCC). Biomass data were provided by Anine Smith from Colorado State University and the U.S. Geological Survey (USGS) from the Northern Prairie Wildlife Research Center.

Cheyenne, $W Y\left(41^{\circ} 6^{\prime} \mathrm{N}-104^{\circ} 53^{\prime} 12^{\prime \prime} \mathrm{W}\right)$ is an upland site. The plant community is approximately $55 \% \mathrm{C}_{3}$ grasses and $25 \% \mathrm{C}_{4}$ grasses (Bachman et al 2010). Pascopyrum smithii is the dominant $\mathrm{C}_{3}$ grass, while Bouteloua gracilis is the dominant $\mathrm{C}_{4}$ grass. Cheyenne United States Department of Agriculture (USDA) Agricultural Research Service (ARS) station provided multiples years of both productivity data and climate data collected from the Prairie Heating and $\mathrm{CO}_{2}$ Enrichment (PHACE) experiment. Additional biomass data were collected by participants of The Extreme Drought in Grasslands Experiment (EDGE) project.

\section{Short grass steppe}

Short Grass Steppe, $C O\left(40^{\circ} 48^{\prime} 46^{\prime \prime} \mathrm{N}-104^{\circ} 27^{\prime} \mathrm{W}\right)$, is an upland site in which the $\mathrm{C}_{4}$ grass Bouteloua gracilis accounts for approximately $70 \%$ of canopy cover and $90 \%$ of total biomass (Dalgleish et al. 2006, Cherwin et al. 2012). Short Grass Steppe is located in the north east portion of Colorado. It is less than $50 \mathrm{~km}$ south east of the Cheyenne site, but it is approximately 265 meters lower in elevation. Short Grass Steppe Long Term Ecological Research (SGS LTER) provided both climate and productivity data for the Short Grass Steppe site. Additional biomass data was collected by participants of The Extreme Drought in Grasslands Experiment (EDGE) project.

Sand Creek Massacre Historical Site, CO (38 $\left.32^{\prime} 51^{\prime \prime} \mathrm{N}-102^{\circ} 30^{\prime} 22^{\prime \prime} \mathrm{W}\right)$ and Fort Union, CO $\left(35^{\circ} 54^{\prime} 35^{\prime \prime} \mathrm{N}-105^{\circ} 0^{\prime} 36^{\prime \prime} \mathrm{W}\right)$ are also dominated by Bouteloua gracilis $\left(\mathrm{C}_{4}\right)$. Karie Cherwin 
from Colorado State University provided productivity data and National Oceanic and Atmospheric Administration (NOAA) (www.ncdc.noaa.gov/cdo-web/datasets) provided the climate data for both Sand Creek and Fort Union.

\section{Desert Grassland}

Sevilleta Blue and Sevilleta Black (-106 58' 0"W 34 $20^{\prime} 29$ "N), are both located in central New Mexico. Their names are derived from their distinctively different plant community compositions. Sevilleta Blue, is dominated by blue grama (Bouteloua gracilis) while Sevilleta Black, is dominated by black grama (Bouteloua eriopoda). Both ANPP data and climate data were jointly provided by Sevilleta Long Term Ecological Research Site (LTER). Additional biomass data were also collected by participants of The Extreme Drought in Grasslands Experiment (EDGE) project. 
Table S2: Coefficients of variation (\%) for the climate data from Figure 1. Climate data are from NOAA (www.ncdc.noaa.gov/cdoweb/datasets). Mean annual precipitation (MAP), growing season precipitation (GS. Precip), mean annual temperature (MAT), and growing season temperature (GS. Temp) are based on $30 \mathrm{yr}$ of data.

\section{Coefficient of Variation (\%)}

\begin{tabular}{lcccc}
\hline Site & MAP & $\begin{array}{l}\text { GS. } \\
\text { Precip }\end{array}$ & MAT & $\begin{array}{l}\text { GS. } \\
\text { Temp }\end{array}$ \\
\hline Fort Keogh & 26.8 & 32.5 & 14.0 & 5.5 \\
Wind Cave & 26.1 & 30.9 & 12.1 & 6.3 \\
Cheyenne & 19.6 & 24.9 & 9.1 & 5.9 \\
SGS & 18.1 & 23.4 & 15.1 & 5.2 \\
Sand Creek & 35.2 & 36.3 & 19.6 & 8.0 \\
Fort Union & 24.5 & 29.6 & 5.2 & 3.7 \\
Sevilleta Blue & 31.9 & 45.9 & 18.7 & 10.9 \\
Sevilleta Black & 31.9 & 45.9 & 18.7 & 10.9 \\
\hline
\end{tabular}


Table S3: Dependent variables and candidate models used to assess patterns of ANPP in the eight grasslands.

Dependent Variables

Total ANPP

Graminoid ANPP

Forb ANPP

Relative $\mathrm{C}_{3}$ ANPP
Simple Regression

Annual Temperature

Annual Precipitation

Growing Season Temperature

Growing Season Precipitation

Annual SPEI

Growing Season SPEI

\section{Parameters}

\section{Multiple Regression}

Annual Temperature

Annual Precipitation

Growing Season Temperature

Growing Season Precipitation

Temperature*Precipitation

\author{
ANCOVA \\ Site \\ Annual Temperature \\ Annual Precipitation \\ Growing Season Temperature \\ Growing Season Precipitation \\ All combinations and interactions
}

\title{
Supplemental Literature Cited
}

Cherwin K, Knapp AK (2012) Unexpected patterns of sensitivity to drought in three semi-arid grasslands. Oecologia. 169: 845-852

Dalgleish HJ, Hartnett DC (2006) Below-ground bud banks increase along a precipitation gradient of the North American Great Plains: a test of the meristem limitation hypothesis.

New Phytologist. 171: 81-89 